Table 1. Infants with retrolental fibroplasia

\begin{tabular}{|c|c|c|c|c|c|c|c|c|c|c|c|c|}
\hline \multirow[t]{2}{*}{ Infant } & \multirow[t]{2}{*}{$\begin{array}{l}\text { Date } \\
\text { of birth }\end{array}$} & \multirow{2}{*}{$\begin{array}{l}\text { Gest. } \\
\text { age } \\
\text { (week) }\end{array}$} & \multirow{2}{*}{$\begin{array}{l}\text { Birth } \\
\text { weight } \\
\text { (g) }\end{array}$} & \multirow{2}{*}{$\begin{array}{l}\text { Cicatrical } \\
\text { RLF stage } \\
\text { OD/OS }\end{array}$} & \multicolumn{3}{|c|}{$\begin{array}{l}\text { Total hours } \\
\mathrm{O}_{2}, \mathrm{FiO}_{2}\end{array}$} & \multicolumn{2}{|c|}{$\begin{array}{l}\text { Total hours } \\
\mathrm{O}_{2}\end{array}$} & \multirow[t]{2}{*}{ Et. } & \multirow[t]{2}{*}{ DPA } & \multirow[t]{2}{*}{ Comment } \\
\hline & & & & & 1.0 & 0.6 & 0.4 & CPAP & Mask & & & \\
\hline 1. & 1977 & 28 & 1200 & $0 / \mathrm{V}$ & 8 & 100 & 100 & 100 & 108 & + & - & IRDS \\
\hline 2. & 1977 & 28 & 950 & $\mathrm{~V} / \mathrm{V}$ & 6 & 72 & 48 & 72 & 54 & + & - & IRDS \\
\hline 3. & 1977 & 31 & 1500 & $\mathrm{~V} / \mathrm{V}$ & - & 48 & 48 & 48 & 48 & + & - & IRDS \\
\hline 4. & 1977 & 29 & 1400 & $\mathrm{~V} / \mathrm{V}$ & - & 60 & 50 & 60 & 50 & - & - & IRDS \\
\hline 5. & 1977 & 30 & 1200 & $\mathrm{~V} / \mathrm{V}$ & - & - & 50 & - & 50 & + & - & Tachypnoe \\
\hline 6. & 1977 & 32 & 1420 & $V / V$ & 6 & 84 & 20 & 84 & 26 & + & - & IRDS \\
\hline 7. & 1978 & 26 & 1150 & $\mathrm{~V} / \mathrm{V}$ & 6 & 186 & 20 & 180 & 32 & + & - & IRDS \\
\hline 8. & 1978 & 33 & 1300 & $V / V$ & - & 40 & 10 & 40 & 10 & - & - & IRDS \\
\hline 9. & 1978 & 32 & 1250 & V/III & - & 30 & 10 & 30 & 10 & - & - & IRDS \\
\hline 10. & 1978 & 27 & 950 & I /II & - & 60 & 70 & - & 130 & + & - & Sepsis \\
\hline 11. & 1979 & 29 & 1100 & $V / V$ & 4 & 200 & 200 & 200 & 204 & - & + & IRDS \\
\hline
\end{tabular}

Et. $=$ Exchange transfusion

$+=$ Staging based on reference 6

cicatrical stages of RLF. The difference is statistically significant using $X^{2}$ test. Our results suggest that DPA treatment is associated with a marked decrease in the incidence of severe RLF among very low birth weight infants.

Several studies have provided clinical and experimental data demonstrating that DPA may act by various pathways of the antioxidant defense mechanism. For example, this drug can serve as a hydrogen and electron donor; can scavenge oxidizing free radicals; can form mixed disulfides with macromolecules; can chelate copper and other heavy metals; and can liberate some of the protein- bound glutathione [5]. Furthermore, liver peroxidase, and of catalase activity; at the same time, it causes a decrease in the lipid peroxidation in the liver of neonate rats [4]. On the basis of the data reported here, it seems very likely that in preventing hyperbilirubinaemia and oxygen toxicity the mechanism of action of DPA is common: the protection of biomembranes against lipid peroxidation.

Finally, we do wish to emphasize that although DPA was administered to our babies in uncommonly high daily doses $\left(300 \mathrm{mg} / \mathrm{kg}\right.$ body weight Metalcaptase ${ }^{\circledR}-$ Knoll AG; Ludwigshafen/Berlin-in 4 DPA treatment leads to an increase in the equal doses intravenously, starting from 12-24 h of life, spreading over 2 to 5 days) compared to those used in adults, no serious side effects have so far been recorded in connection with more than 2,000 infants treated in our Department in the last eight years. The drug has no bilirubin displacing effect on the albumin-bilirubin complex using in vitro or in vivo methods [1]. Consequently, concerning risk versus benefit in the approach to DPA therapy of neonates, the data of the present study provide support for conducting further controlled clinical trials.

\section{References}

1. Brodersen R, Lakatos L, Karmazsin L (1980) D-Penicillamine, a non-bilirubindisplacing drug in neonatal jaundice. Acta paediat scand $69: 31-35$

2. James LS, Lanman JT (1976) History of oxygen therapy and retrolental fibroplasia. Pediatrics (Suppl) $57: 591-642$

3. Lakatos L, Kövér B, Oroszlán Gy, Vekerdy Zs (1976) D-Penicillamine therapy in AB0 hemolytic disease of the newborn infant. Europ J Pediat $123: 133-137$

4. Matkovics B, Lakatos L, Szabó L, Karmazsin L (1981) Effects of D-Penicillamine on some oxidative enzymes of rat organs in vivo. Experientia $37: 79-80$

5. Munthe E, Jellum E, Asseth J (1979) Some aspects of the mechanism of action of penicillamine in rheumatoid arthritis. Scand J Rheumat $28: 6-12$

6. Reese AB, King M, Owens WC (1953) Classification of retrolental fibroplasia. Amer J Ophthal $38: 1333-1335$

Received August 26, $1981 /$

Accepted September 17, 1981

\title{
Second Announcement
}

\section{International Symposium on Niemann-Pick Disease 1982}

The first Announcement was sent out in summer and autumn of 1981. Those who have not yet responded should contact Dr. M. Elleder, the Hlava Institute of Pathology, Faculty of Medicine, Studničkova 2, 12888 Prague 2, Czechoslovakia.

Date of the Session - Important!
We regret to inform you that the date of the Symposium had to be shifted owing to a change in the date of the Vienna Congress of Neuropathology and of the beginning of the Academic year at our university. The Symposium will, therefore, not take place on September 13-14 as originally planned but on September 2 (Thursday) and 3 (Friday). 